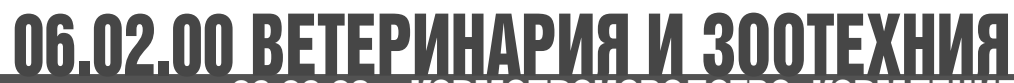

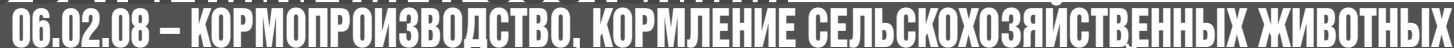

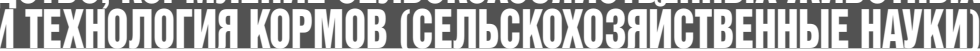 \\ ПОКАЗАТЕЛИ ОБМЕНА ВЕЩЕСТВ У ИНДЕЕК НА ФОНЕ СКАРМЛИВАНИЯ МОДИФИЦИРОВАННОГО ЦЕОЛИТА И СОЕВОЙ ОКАРЫ
}

Воротникова Ирина Алексеевна, аспирант кафедры «Морфология, физиология и патология животных»

Дежаткина Светлана Васильевна, доктор биологических наук, профессор кафедры «Морфология, физиология и патология животных»

ФГБОУ ВО УЛьянОвСКИЙ ГАУ

432017, г. Ульяновск, бульвар Новый Венеи, 1; тел.: 8(8422)55-23-75;

e-mail:dsw1710@yandex.ru

Ключевые слова: индейка, добавка, обмен веществ, белок, ферменты.

Цель работы - изучить показатели обмена веществ у молодняка индеек при введении в их рацион комплексной добавки на основе модифицированного цеолита и соевой окары. Для физиологического опыта молодняк индеек кросса Hybrid Grade Maker подобрали в группы аналогов по 10 в каждой. Для научно-производственного эксперимента было взято 1500 птиц. Молодняк индеек 40..45-дневного возраста разделили на группы: 1-я - контроль, 2-я - опыт. Опыты проводили в Ульяновской области на базе крестьянско-фрермерского хозяйства. Схема кормления заключалась в том, что 1-й группе индеек скармливали только основной рацион (OP) хозяйства, а 2-й дополнительно в ОР вводили комплексную добавку в количестве 100 г/гол/сут. Исследование гематологических и биохимических показателей проводили современными методами, используя автоматические анализаторы. Кровь брали из подкожной подкрыльцовой вены птиц до утреннего кормления. Обработку данных вели по программе "Statistika". Установлено положительное влияние комплексной добавки на морфологический состав крови индеек и уровень их обмена веществ, в т.ч. повышение анаболических процессов, реакций переаминирования аминокислот, усиления гликолиза при уменьшении липогенеза.

\section{Введение}

В настоящее время мировое и отечественное птицеводство является динамично развивающейся отраслью АПК, которая обеспечивает население продуктами питания, в том числе мясом индейки [1]. Однако при неправильном и однообразном кормлении у птиц возникают нарушения основных процессов в организме, развиваются патологии, что способствует падежу , процент которого доходит до 35 [2, 3]. Наукой и практикой доказано, что при дефиците в рационе птиц протеина, аминокислот, минеральных элементов и витаминов или плохой их усвояемости у птицы возникают патологии обмена веществ, вследствие этого резко снижается уровень её продуктивности $[4,5]$. Поэтому профилактика нарушений обменных процессов у птиц в настоящее время крайне актуальна [6, 7]. Одной из эффективных форм профилактики и коррекции нарушения обмена веществ как у животных, так и у птиц является использование высокоэффективных подкормок на основе природных, натуральных и биологически активных компонентов [8, 9]. Большой научный интерес в этом плане имеет модифицированный цеолит как энтеросорбент и ионообменник, источник макро- и микроэлементов, а также соевая окара, не токсичный отход соевого производства, богатый белком, аминокислотами, витаминами и легкоусвояемым железом [10, 11].

Цель работы - изучить показатели состава крови и обмена веществ у молодняка индеек при введении в их рацион комплексной добавки на основе модифицированного цеолита и соевой окары.

\section{Объекты и методы исследований}

Для эксперимента были выбраны птицы молодняк индеек кросса Hybrid Grade Maker. Opганизованы и проведены эксперименты: научнохозяйственный (на 1500 индейках) и физиологический опыт (на 20 птицах). Сформированы две группы аналогов по 10 в каждой из птиц 40..45-дневного возраста. Опыты проводились в Ульяновской 
Таблица 1 области на базе крестьянско-фермерского

Гематологические показатели индеек при применении комплексной добавки

\begin{tabular}{|c|c|c|c|c|}
\hline \multirow[b]{2}{*}{ Показатель, ед. } & \multicolumn{4}{|c|}{ Группа птиц } \\
\hline & 1 -контроль & $\%$ & 2 - опыт & $\begin{array}{c}\text { от кон- } \\
\text { троля \% }\end{array}$ \\
\hline Эритроциты, *1012/л & $2,30 \pm 0,16$ & 100 & $2,47 \pm 0,128$ & 107,39 \\
\hline Лейкоциты, *109/л & $20,57 \pm 0,30$ & 100 & $21,31 \pm 0,18$ & 103,60 \\
\hline Гемоглобин, г/л & $163,33 \pm 7,51$ & 100 & $172,67 \pm 2,91$ & 105,72 \\
\hline Гематокрит, \% & $34,23 \pm 2,33$ & 100 & $35,83 \pm 1,60$ & 104,67 \\
\hline
\end{tabular}

Таблица 2

Содержание общего белка и его фракций в сыворотке крови индеек при введении в их рацион добавки

\begin{tabular}{|l|c|c|}
\hline \multicolumn{1}{|c|}{ Показатель } & 1 - контроль & 2 - опыт \\
\hline Общий белок, г/л & $42,04 \pm 1,27$ & $44,89 \pm 1,17$ \\
\hline$\%$ от контроля & 100 & 106,78 \\
\hline Альбумины, $\%$ & $31,40 \pm 0,57$ & $33,72 \pm 0,84^{*}$ \\
\hline$\%$ от контроля & 100 & 107,38 \\
\hline$\alpha$-глобулины, \% & $16,13 \pm 0,27$ & $17,63 \pm 0,65$ \\
\hline$\%$ от контроля & 100 & 109,29 \\
\hline$\beta$-глобулины, \% & $9,34 \pm 0,16$ & $9,95 \pm 0,18$ \\
\hline$\%$ от контроля & 100 & 106,53 \\
\hline ү-глобулины, \% & $29,06 \pm 0,67$ & $30,11 \pm 0,58$ \\
\hline$\%$ от контроля & 100 & 103,6 \\
\hline А/Г коэффициент & $0,57 \pm 0,02$ & $0,58 \pm 0,01$ \\
\hline \% от контроля & 100 & 102,0 \\
\hline \multicolumn{2}{|c|}{ Примечание: ${ }^{*}-(p<0,05)$ по сравнению с по- } \\
казателем в контрольной группе
\end{tabular}

Таблица 3

Биохимические показатели крови индеек при скармливании комплексной подкормки

\begin{tabular}{|l|c|c|}
\hline \multicolumn{1}{|c|}{ Показатель, ед. } & 1 - контроль & 2- опыт \\
\hline АсАТ, нкат/л & $721,83 \pm 12,31$ & $689,27 \pm 10,93$ \\
\hline$\%$ от контроля & 100 & 95,49 \\
\hline АлАТ, нкат/л & $614,25 \pm 8,96$ & $635,94 \pm 14,98$ \\
\hline$\%$ от контроля & 100 & 102,75 \\
\hline $\begin{array}{l}\text { Соотношение } \\
\text { АсАТ/АлАТ }\end{array}$ & 1,17 & 1,08 \\
\hline Щ, нкат/л & $2750,90 \pm 94,27$ & $2621,70 \pm 147,46$ \\
\hline$\%$ от контроля & 100 & $95,3 \%$ \\
\hline Глюкоза, ммоль/л & $7,48 \pm 0,28$ & $7,95 \pm 0,32$ \\
\hline$\%$ от контроля & 100 & 106,3 \\
\hline $\begin{array}{l}\text { Холестерин, } \\
\text { ммоль/л }\end{array}$ & $3,49 \pm 0,1$ & $3,28 \pm 0,08$ \\
\hline$\%$ от контроля & 100 & 94 \\
\hline
\end{tabular}

Примечание: $p>0,05$ по сравнению с показателем в контрольной группе хозяйства ИП ГКФП «Санкеев С.А.». Схема кормления заключалась в следующем: 1-й контрольной группе скармливали только основной рацион (ОР) хозяйства, а 2-й (опыт) - в ОР вводили комплексную добавку в количестве 100 г/гол/сут. Добавка состоит из двух основных компонентов (1:1): модифицированного цеолита (приготовленного по новой инновационной технологии, которая позволяет в несколько раз усилить его полезные свойства и включает: три стадии активации карьерного цеолита, его обжига при высоких температурах до $600{ }^{\circ} \mathrm{C}$ и ультразвуковую обработку) и соевой окары - отхода производства соевого молока. Исследование состава крови птиц проводили современными методами, используя ветеринарный гематологический анализатор «PCE-90Vet» и биохимический анализатоpa «StatFax 1904 Plus», общий белок и его фракции исследовались акустическим методом на анализаторе «АКБа-О1-БИОМ». Пробы крови брали из подкожной подкрыльцовой вены до утреннего кормления. Данные обрабатывали с помощью программы "Statistika".

\section{Результаты исследований}

Анализ полученных данных показал, что за период опыта 45 дней у молодняка индеек всех групп показатели морфологического состава крови находились в рамках физиологических норм для этой породы и возраста птиц. При этом птицы, получавшие комплексную добавку к рациону, характеризовались лучшими гематологическими параметрами по сравнению с контролем (табл. 1).

Это подтверждается выраженной тенденцией к увеличению ряда показателей крови: числа эритроцитов на 7,39 \%, количества лейкоцитов на 3,6 $\%$, уровня гемоглобина на 5,72 \%, показателя гематокрита на 4,67 \% по сравнению с аналогами в 1-й группе. Выявленная закономерность благоприятного влияния скармливания добавки на морфологический состав крови птиц, в том числе показателей красной крови (эритроцитов и гемоглобина) является косвенным фактором, указывающим на повышение дыхательной функции их крови и инициации функциональной активности костного мозга.

В ходе опыта установлено, что скармливание модифицированного цеолита в комплексе с соевой окарой оказало положительное влияние на ряд биохимических показателей у птиц. Добавление в рацион индеек 2-й группы комплексной подкормки способствовало чёткой тенденции к повышению содержания общего белка на 6,78 \% и его фракций (табл. 2). 
В спектре белковых фракций сыворотки крови птиц опытной группы выявлено достоверное увеличение уровня альбуминов на 7,38 \% $(p<0,05)$, что характеризует повышение анаболических процессов в их организме. Содержание глобулиновых фракций в крови птиц 2-й группы также имело тенденцию к увеличению, в частности а-глобулинов на 9,29\%, $\beta$-глобулинов - на 6,53 \% и ү-глобулинов на - 3,6 \% по сравнению с контролем. При этом отмечено повышение альбумино-глобулинового коэффициента,

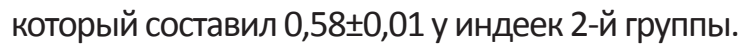

Одним из ключевых ферментов белкового обмена являются аминотрансферазы. Полученные нами данные свидетельствуют о том, что включение комплексной добавки в рацион молодняка индеек способствует тенденции к снижению в пределах физиологических норм (табл. 3). В частности активность основного фермента, характеризующего белковый обмен аспартатаминотрансферазы (АсАТ) снижалась на 5,51 \%, в то время, как активность аланинаминотрансферазы (АлАТ) слабо возрастала на 2,75 \% по сравнению с данными в контроле. В целом эти данные свидетельствуют об усилении процессов переаминирования аминокислот.

На этом фоне в крови птиц 2-й группы отмечено также снижение в рамках норм активности щелочной фосфатазы (ЩФ) на 4,7 \% по сравнению с аналогами. Это может указывать на снижение нагрузки на печень птиц.

Основным критерием углеводного обмена является концентрация глюкозы в крови. По нашим сведениям этот показатель у индеек 2-й

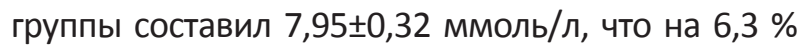
больше, чем у сверстников в 1-й группе. Это может говорить о более активном использовании углеводных субстратов в качестве энергетического сырья, что обеспечивает высокую интенсивность метаболических реакций, в том числе процесса гликолиза.

Важным параметром липидного обмена является содержание холестерина в крови. Так экспериментально установлено, что в крови индеек, получавших комплексную добавку, происходило заметное снижение в рамках норм этого показателя на 6 \% по сравнению с контролем, косвенно указывая на уменьшение липогенеза.

\section{Выводы}

1. Поступление в организм молодняка индеек комплексной добавки на основе модифицированного цеолита и соевой окары оказывает благоприятное воздействие на морфологический состав их крови.
2. Скармливание комплексной добавки птице опытной группы способствует интенсивности обмена веществ в их в организме, в том числе повышению анаболических процессов, реакций переаминирования аминокислот, усиления гликолиза на фоне уменьшения липогенеза.

\section{Библиографический список}

1. Морарь, М.А.Перспектива развития производства индеек в России / М. А. Морарь, Е. С. Вайскробова // Молодой ученый. - 2016. - № 14. - С. 368-371.

2. Дубровская, В. И. Продукты из мяса индейки / В. И. Дубровская, В. А. Гоноцкий // Птица и птицепродукты. - 2013. - № 3. - С. 30-32.

3. Фисинин, В. И. Состояние и вызовы будущего в развитии мирового и российского птицеводства / В. И. Фисинин // Инновационное обеспечение яичного и мясного птицеводства России : Международная конференция. - Сергиев Посад, 2015. - С. 9-25.

4. Жуков, И. В. Изучение причин нарушений обмена веществ и низкой напряжённости специфического иммунитета у кур-несушек / И. В. Жуков, А. А. Ушакова // Вестник Воронежского государственного университета инженерных технологий. - 2015. - № 4. - С. 125-128.

5. Влияние наноразмерного фосфорита на метаболизм и росто-весовые показатели птицы мясной продуктивности / А. П. Герасимов, В. О. Ежков, А. М. Ежкова, И. А. Яппаров // Вестник Казанского технологического университета. - 2014. - Т.7, № 17. - С. 213-216.

6. Влияние комплексной белковой добавки на организм животных / В. Г. Вертипрахов, О. П. Шеломенцева, М. Н. Бутенко, О. Т. Андреева // Ученые записки Забайкальский государственный гуманитарно-педагогический университет им. Н.Г. Чернышевского. - 2012. - Т.1, № 42. - С. 108-114.

7. Любин, Н. А. Физиологические механизмы при скармливании цеолитов продуктивным животным / Н. А. Любин // Роль аграрной науки в устойчивом развитии сельских территорий : Всероссийская (национальная) научная конференция. - Новосибирск, 2017. - 203-208.

8. Дежаткина, С. В. Динамика живой массы индеек при скармливании комплексной нанодобавки / С. В. Дежаткина, И. А. Никитина, М. Е. Дежаткин // Аграрная наука и образование на современном этапе развития: опыт, проблемы и пути их решения : Международная научно-практическая конференция. -Ульяновск, 2018. - С. 40-45.

9. Ганиев, А. Н. Наносырье в качестве кормовых добавок / А. Н. Ганиев, М. Е. Дежаткин // 
Научно-методический электронный журнал «Концепт». - 2017. - Т. 39. - С. 466-470.

10. Мухитов, А. 3. Использование отхода производства в питании животных / А. З. Мухитов // Роль аграрной науки в устойчивом развитии сельских территорий : Всероссийская (национальная) научная конференция. - 2017. - С. 218-222.
11. Использование соевой окары в качестве белковой добавки сельскохозяйственной птице / С. В. Дежаткина, В. В. Ахметова, Н. В. Силова, С. Г. Писалева // Восточное партнерство : Международная научно-практическая конференция. - 2013. - C. $70-76$.

\title{
TURKEY METABOLISM PARAMETRES IN CASE OF FEEDING THEM WITH MODIFIED ZEOLITE AND SOY OKARA
}

\author{
Vorotnikova I.A., Dezhatkina S.V. \\ FSBEI HE Ulyanovsk State Agrarian University \\ 432017, Ulyanovsk, Novyi Venets boulevard, 1; tel .: 8 (8422) 55-23-75; \\ e-mail: dsw1710@yandex.ru
}

Key words: turkey, supplement, metabolism, protein, enzymes.

The purpose of the work is to study metabolic parametres of young turkeys when a complex supplement based on modified zeolite and soy okara is introduced into their ration. Young Hybrid Credmeyker turkeys were selected into analog groups of 10 in each for physiological test. For research and production test, 1,500 birds were taken. Young turkeys of $40 . .45$ days old were divided into groups: 1 st - control, 2nd - test group. The experiments were carried out in Ulyanovsk region on the basis of an agricultural enterprise. The feeding scheme was the following: the 1st group of turkeys was given only the main ration, as for the 2nd, a complex supplement was additionally introduced into the main ration at the dose of of $100 \mathrm{~g}$ per head / day. The study of hematological and biochemical parameters was carried out by modern methods using automatic analyzers. Blood was taken from saphenous axillary vein of birds before morning feeding. Data processing was carried out with "Statistika" program. A positive effect of the complex additive on morphological composition of turkey blood and the level of their metabolism, including increased anabolic processes, amino acid transamination reactions, enhanced glycolysis with a decrease of lipogenesis was stated.

\section{Bibliography}

1. Morar, M. A. Development prospect of turkey production in Russia / M. A. Morar, E. S. Vayskrobova // Young scientist. - 2016. - No. 14. - P. 368-371.

2. Dubrovskaya, V.I. Products from turkey meat / V.I. Dubrovskaya, V.A. Gonotsky// Poultry and poultry products. - 2013. - No. 3. - P. 30-32.

3. Fisinin, V. I. The state and challenges of the future in development of world and Russian poultry farming / V. I. Fisinin // Innovative support of egg and meat poultry farming in Russia: International Conference. - Sergiev Posad, 2015 --- P. 9-25.

4. Zhukov, I. V. The study of metabolic disorder reasons and low tension of specific immunity of laying hens /I. V. Zhukov, A. A. Ushakova // estnik of Voronezh State University of Engineering Technologies. - 2015. - No. 4. - P. 125-128.

5. The effect of nanosized phosphorite on metabolism and growth-weight parametres of poultry meat productivity / A. P. Gerasimov, V. O. Ezhkov, A. M. Ezhkova, I. A. Yapparov // Vestnik of Kazan Technological University. - 2014. - V.7, No. 17. - P. 213-216.

6. The effect of complex protein supplements on animals / V. G. Vertiprakhov, O. P. Shelomentseva, M. N. Butenko, O. T. Andreeva // Scientific notes of Zabaykalsky State Humanitarian and Teacher Training University named after N.G. Chernyshevsky. - 2012. - V.1, No. 42. - P. $108-114$.

7. Lyubin, N. A. Physiological mechanisms in case of giving zeolites to productive animals / N. A. Lyubin // The role of agricultural science in sustainable development of rural territories: All-Russian (national) scientific conference. - Novosibirsk, 2017._P. 203-208.

8. Dezhatkina, S.V. Dynamics of live weight of turkeys in case of feeing them with complex nano-additives / S.V. Dezhatkina, I. A. Nikitina, M. E. Dezhatkin // Agricultural science and education at the present stage of development: experience, problems and solutions: International scientific-practical conference. Ulyanovsk, 2018 .-- P. 40-45.

9. Ganiev, A. N. Nano materials as feed additives / A. N. Ganiev, M. E. Dezhatkin // Scientific and methodical electronic journal "Concept". - 2017. - V. 39. - P. 466-470.

10. Mukhitov, A. Z. Use of industrial waste in animal nutrition / A. Z. Mukhitov // The role of agricultural science in sustainable development of rural territories: All-Russian (national) scientific conference. - 2017.-- P. 218-222.

11. Usage of soy okara as protein supplement for poultry/S. V. Dezhatkina, V. V. Akhmetova, N. V. Silova, S. G. Pisaleva // Eastern Partnership: International Scientific and Practical Conference. - 2013 .-- P. 70-76. 